\title{
Karyological Studies in Five Wild Species of Amaranths
}

\author{
Eduardo J. Greizerstein ${ }^{1,2}$, Carlos A. Naranjo ${ }^{1}$ and Lidia Poggio ${ }^{1,2}$ \\ ${ }^{1}$ Instituto Fitotécnico de Sta. Catalina (FCAF, UNLP)-Centro de Inv. Genéticas \\ (UNLP-CONICET), Casilla de Correo 4, 1836 Llavallol, Argentina, and \\ ${ }^{2}$ Departamento de Cs. Biológicas (FCEN, UBA), Argentina
}

Accepted January 22, 1997

A cytogenetic program in Amaranthus have been devised in our laboratory since 1988, in order to improve the karyological characterization of the species and cultivars, increase the knowledge of genetic resources and explore evolutionary trends (Greizerstein and Poggio 1992, 1994, 1995).

Two chromosome numbers have been reported in the genus $(2 n=32,2 n=34)$ and in some cases both numbers occur in the same species, in addition to that of $A$. dubius $\mathrm{L}$, the only species with $2 n=64$. Pal et al. (1982) suggested that the gametic number $n=17$ originated from the $\mathrm{n}=16$ through primary trisomy. Greizerstein and Poggio $(1992,1994)$, on the basis of the cytogenetic analysis of interspecific hybrids support this hypothesis, and propose that the species with $2 n=32$ are polyploids (basic number $x=8$ ) and that $x_{1}=16$ is a derived basic number. The basic number $\mathrm{x}_{2}=17$ would have appeared later by primary trisomy.

In the present contribution we report the karyotype formulae and total DNA content of five wild species namely $A$. bouchonii Thellung., A. hybridus L., A. quitensis L., A. powelli Wats and $A$. spinosus $\mathrm{L}$. with the aim of increasing the cytogenetic knowledge of this important genus.

\section{Materials and methods}

The material was provided by Ing. Agr. Guillermo Covas and was cultivated at the Instituto Fitotécnico Santa Catalina (IFSC), Llavallol, Pcia. de Buenos Aires, Argentina. Amaranthus bouchonii (cult. No. 90-851, 92-423, 93-577). A. hybridus (cult. No. 89-322, 89327, 90-841, 90-862, 91-433, 92-464). A. powellii (cult. No. 90-877, 91-423, 92-452). $A$. quitensis (cult. No. 89-311, 90-860, 91-429, 91-476, 92-497, 92-498, 91-430, 91-500, 92-496). A. spinosus (cult. No. 89-320, 90-832, 91-437, 92-412, 92-454).

Karyotype analysis: The observations have been done on root tip cells of germinating seeds. Pretreatment with colchicine $0.05 \%$ during $2-3 \mathrm{hr}$ at room temperature in darkness, fixation in absolute ethanol-acetic acid $(3: 1)$ and stain with acetic-haematoxylin $2 \%$. The nomenclature used for the description of the chromosome morphology is that proposed by Levan et al. (1964). To estimate the karyotype asymmetry, two numerical parameters were used according to Romero Zarco (1986): $A_{1}=$ (intrachromosomal asymmetry index) and $A_{2}=$ (interchromosomal index). Both indexes are independent of chromosome number and size.

Determination of DNA content: DNA content was measured in telophase nuclei $(2 \mathrm{C})$ of the root apex of germinated seeds, following the procedure described by Tito et al. (1991). The optimal hydrolysis time was $45 \mathrm{~min}$. The amount of Feulgen staining per nucleus, expressed in arbitrary units, was measured at a wavelength of $570 \mathrm{~nm}$, using the scanning method with a Zeiss Universal microphotometer (UMSP 30). The DNA content per basic genome (2C value), expressed in picograms was calculated calibrating a cultivar of Amaranthus cruentus cv Don Guiem with Allium cepa var ailsa craig $(2 C=33.55 \mathrm{pg}$, Bennett and Smith 1976) and the DNA content was calculated using $A$. cruentus cv Don Guiem $(2 \mathrm{C}=1.26 \mathrm{pg})$ as a standard. For each species, two accessions and 2-4 individuals in each one were measured. The 
differences in DNA content were tested by analysis of variance (ANOVA), and comparisons between means were performed using Scheffe's method.

\section{Results}

The somatic chromosome number, the karyotype formulae, the asymmetry indexes and the DNA content of $A$. bouchonii L., A. hybridus L., A. quitensis, $A$. powelli and $A$. spinosus are indicated in Table 1. In order to compare the wild species with the cultivated ones, the previous data from $A$. caudatus $(2 \mathrm{n}=32), A$. cruentus $(2 \mathrm{n}=34), A$. hypochondriacus $(2 \mathrm{n}=32)$ and $A$. mantegazzianus $(2 \mathrm{n}=32)$ (Greizerstein and Poggio 1994) are included in Table 1. The species differ in the karyotype formulae and show differences in their asymmetry indexes $A_{1}$ and $A_{2}$. The karyograms of the five wild species are showed in Fig. 2. One pair of chromosomes with a satellite is present in all species. Since chromosomes are very small (ca. $1 \mu \mathrm{m})$ it is not easy to identify the chromosome with the secondary constriction in all the studied cells.

Since the ANOVA test showed non-significant differences in DNA content within species, data were pooled for each species. The analysis of variance shows the existence of significant differences among species $\left(\mathrm{F}_{8,403}=51.96, \mathrm{P}>0.001\right)$. Scheffe's tests indicate that $A$. mantegazzianus and $A$. bouchonii have no significant differences between them but significant ones with all the other species analyzed. A. caudatus have significant differences with the first two, and with the others species, while $A$. cruentus, $A$. hybridus, $A$. hypochondriacus, $A$. quitensis and $A$. spinosus, do not differ significantly in their DNA content (Table 1).

\section{Discussion}

Several authors have reported the chromosome number for the wild species studied in the present paper: $A$. bouchonii $2 \mathrm{n}=32$ (Hügin 1987), A. hybridus 2n=32 (Grant 1959, Queiros 1989) and $2 \mathrm{n}=34$ (Pal and Pandley 1989), A. powellii $2 \mathrm{n}=32$ (Hügin 1987) and $2 \mathrm{n}=34$ (Kiehn et al. 1991), A. quitensis $2 \mathrm{n}=32$ (Grant 1959), A. spinosus $2 \mathrm{n}=34$ (Paiva and Leitao 1989).

The results obtained in a previous work (Greizerstein and Poggio 1994) and in the present contribution point out that adequate techniques allow the description of the chromosome morphology, total DNA content and reveal karyotype differences among species in spite of their small chromosome size.

There is a taxonomical controversy about the taxonomic status of $A$. bouchonii $(2 \mathrm{n}=32)$. The European taxonomists consider it as a separate species, while the American ones regard it as co-specific of $A$. powelli $(2 \mathrm{n}=34)$ (Wilkin 1992). This author, based on morphological and isoenzymatic studies, proposed to maintain $A$. bouchonii as an independent taxa. The results obtained in the present work support his proposal, since differences in chromosome number, chromosomal asymmetry and total DNA content were found between both species.

The species with $2 \mathrm{n}=34$ chromosomes, $A$. cruentus, $A$. powellii and $A$. spinosus, together with $A$. quitensis $(2 \mathrm{n}=32)$ and $A$. hypochondriacus $(2 \mathrm{n}=32)$ possess the lowest total DNA content. In general, changes in DNA content involve gain or loss of constitutive heterochromatin, which comprises most of the satellite DNA (Price 1988a,b, Flavell 1986). The C-banding technique showed $\mathrm{C}+$ bands in most of the chromosomes of $A$. mantegazzianus, $A$. caudatus and $A$. bouchonii (species with higher DNA content). On the other hand, the species with lower DNA content (A. cruentus, A. hypochondriacus, $A$. spinosus, $A$. powelli and $A$. quitensis) showed C + blocks only in 1-3 chromosome pairs (Greizerstein 1995). These results suggest that differences in DNA content among species could be attributed, at least in part, to differences in heterochromatin content. Bennett (1987) has established that the variation of the 



Fig. 1. A-D Mitotic metaphases which were used to make the karyograms of Fig. 2. A. $A$. bouchonii $(2 \mathrm{n}=32)$. B. A. hybridus $(2 \mathrm{n}=32)$. C. A. quitensis $(2 \mathrm{n}=32)$. D. A. powelii $(2 \mathrm{n}=34)$. E. A. spinosus $(2 \mathrm{n}=34)$. $B a r=10 \mu \mathrm{m}$.

C-value of DNA content has a remarkable adaptative and ecological meaning; moreover, genome size is positively correlated with minimum generation time (Bennett 1987), as was demonstrated in several lines and populations of maize (Tito et al. 1991).

When asymmetry indexes $A_{1}$ and $A_{2}$ were plotted it could be seen that the grain species and A. bouchonii had more symmetrical karyotypes than the rest of the studied species (Fig. 3). The 


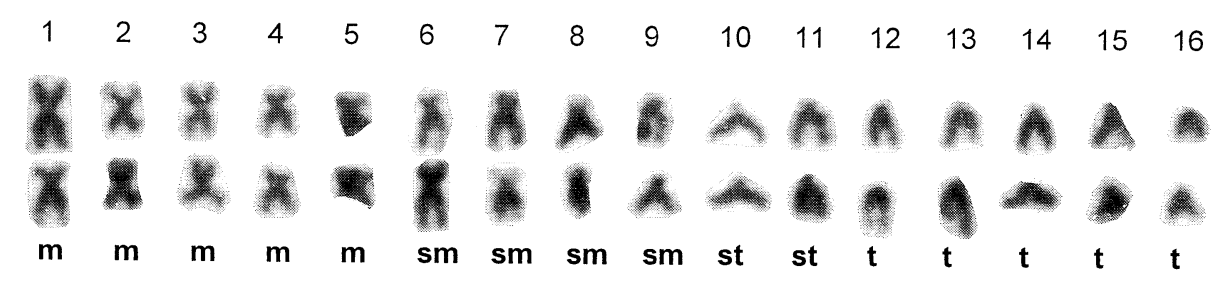

A. bouchonii

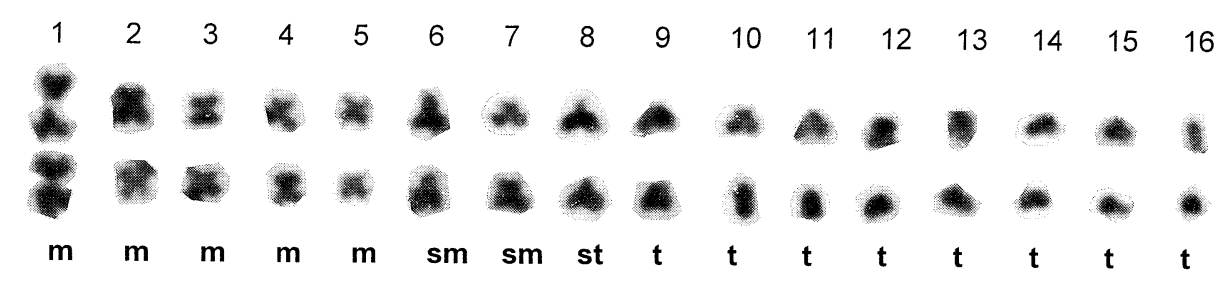

A. hybridus

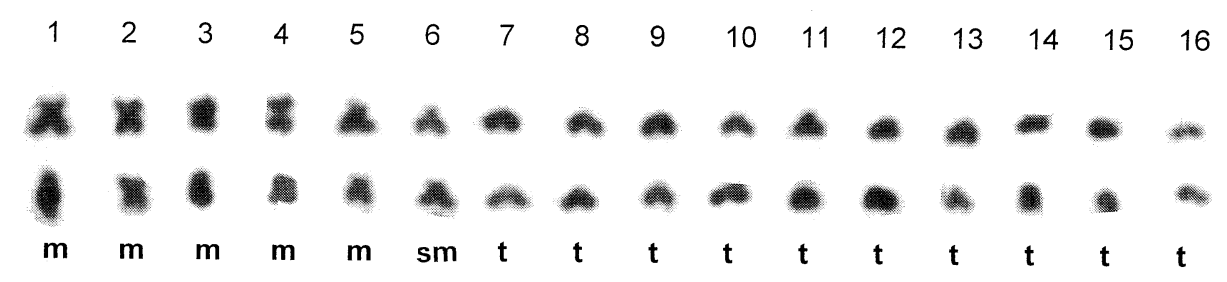

A. quitensis

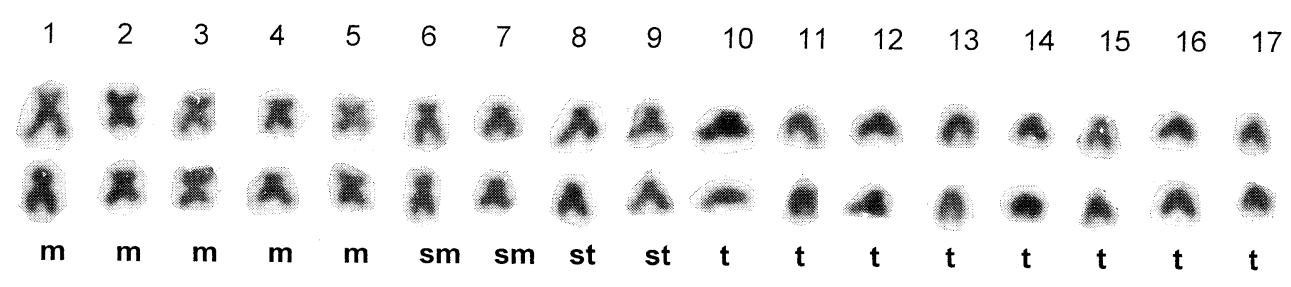

A. powellii

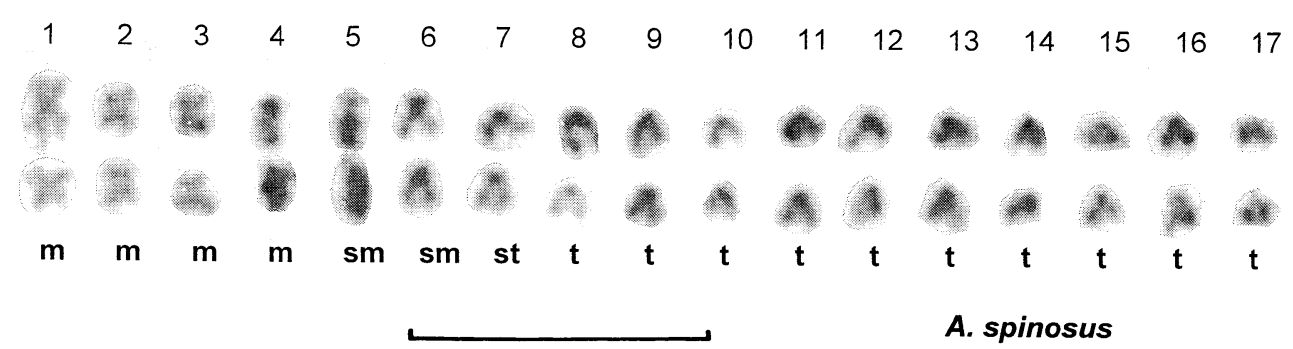

Fig. 2. Karyograms of the five wild species. $B a r=10 \mu \mathrm{m}$.

results obtained indicate that cytogenetical analyses allow to differenciate the species of Amaranthus and solve some taxonomical controversies. The existence of accessions with $2 \mathrm{n}=$ 34 and $2 n=32$ chromosomes for the same species, as in A. hypochondriacus (Palomino and 
Table 1. Chromosome number, karyotype formulae, asymmetry indexes $\left(A_{1}\right.$ and $\left.A_{2}\right)$ and DNA content of the five wild species studied

\begin{tabular}{lllllc}
\hline \hline \multicolumn{1}{c}{ Species } & Kn & Karyotype formulae & $\mathrm{A}_{1}$ & $\mathrm{~A}_{2}$ & $\begin{array}{c}\text { DNA content } \\
(2 \mathrm{C}) \mathrm{pg}^{*} \\
\mathrm{X} \pm \mathrm{SE}\end{array}$ \\
\hline A. bouchonii & 32 & $5 \mathrm{~m}+4 \mathrm{sm}+2 \mathrm{st}+5 \mathrm{t}$ & 0.58 & 0.26 & $1.61 \pm 0.014^{\mathrm{a}}$ \\
A. caudatus** & 32 & $5 \mathrm{~m}+3 \mathrm{sm}+8 \mathrm{t}$ & 0.61 & 0.25 & $1.35 \pm 0.013^{\mathrm{b}}$ \\
A. hybridus & 32 & $5 \mathrm{~m}+2 \mathrm{sm}+1 \mathrm{st}+8 \mathrm{t}$ & 0.61 & 0.36 & $1.28 \pm 0.014^{\mathrm{c}}$ \\
A. hypochondriacus** & 32 & $5 \mathrm{~m}+4 \mathrm{sm}+1 \mathrm{st}+6 \mathrm{t}$ & 0.60 & 0.24 & $1.26 \pm 0.018^{\mathrm{c}}$ \\
A. mantegazzianus** & 32 & $5 \mathrm{~m}+3 \mathrm{sm}+8 \mathrm{t}$ & 0.61 & 0.37 & $1.46 \pm 0.015^{\mathrm{a}}$ \\
A. quitensis & 32 & $5 \mathrm{~m}+1 \mathrm{sm}+10 \mathrm{t}$ & 0.72 & 0.31 & $1.24 \pm 0.015^{\mathrm{c}}$ \\
A. cruentus** & 34 & $3 \mathrm{~m}+7 \mathrm{sm}+7 \mathrm{t}$ & 0.70 & 0.22 & $1.26 \pm 0.013^{\mathrm{c}}$ \\
A. powellii & 34 & $5 \mathrm{~m}+2 \mathrm{sm}+2 \mathrm{st}+8 \mathrm{t}$ & 0.71 & 0.25 & $1.25 \pm 0.018^{\mathrm{c}}$ \\
A. spinosus & 34 & $4 \mathrm{~m}+2 \mathrm{sm}+1 \mathrm{st}+10 \mathrm{t}$ & 0.71 & 0.27 & $1.25 \pm 0.012^{\mathrm{c}}$ \\
\hline
\end{tabular}

* Species without significant differences in DNA content are showed with the same letters. **Data from Greizerstein and Poggio (1994).

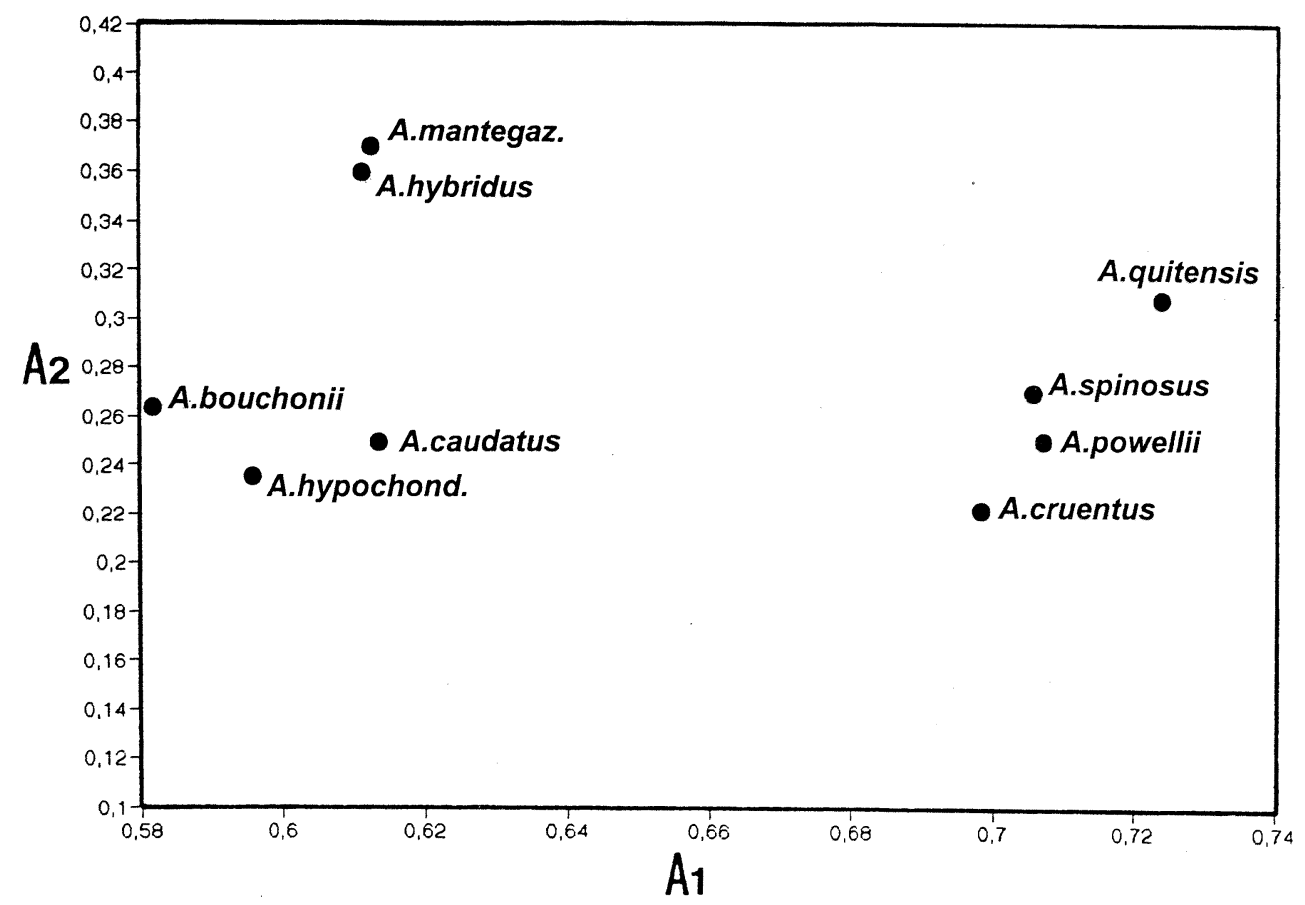

Fig. 3. Dispersion diagram representing the karyotype asymmetry.

Rubi 1991) points out that the knowledge of cytological features could predict segregational sterility in some intra or interspecific crosses.

\section{Summary}

The karyotypes and total DNA content of five wild species of Amaranths (Amaranthus bouchonii $(2 \mathrm{n}=32)$, A. hybridus $(2 \mathrm{n}=32)$, A. quitensis $(2 \mathrm{n}=32), A$. powellii $(2 \mathrm{n}=34)$ and $A$. spinosus $(2 \mathrm{n}=34))$ were studied. These data are compared with that of the four grain species. The results indicate that this kind of studies allows the differenciation of these nine species of Amaranthus. There are differences in the karyotype formulae and asymmetry indexes $A_{1}$ and 
A2. Moreover, this kind of studies let some taxonomical controversies be solved, for instance, to maintain $A$. bouchonii as a independent taxa of $A$. powellii.

\section{Acknowledgements}

The authors thank Prof. Ing. Agr. Guillermo Covas for having provided the materials. This work has been supported by grants of the Buenos Aires University, National University of La Plata and Argentine Research Council (CONICET).

\section{References}

Bennett, M. D. 1987. Variation in genomic form in plants and its ecological implications. New Phytol. 106: 177-200.

Flavel, R. B. 1986. Repetitive DNA and chromosome evolution in plants. Philos. Trans. R. Soc. London Ser B 274: 227-274.

Grant, F. W. 1959. Cytogenetic studies in Amaranthus III. Chromosome numbers and phylogenetic aspects. Can. J. Genet. Cytol. 1: 313-318.

Greizerstein, E. J. 1995. Estudios Citogenéticos y de electroforesis de proteinas seminales en el género Amaranthus (Amaranthaceae). Ph. D. thesis, 180 pp.

- and Poggio, L. 1992. Estudios citogenéticos de seis hibridos interespecificos de Amaranthus (Amaranthaceae). Darwiniana 31(1-4): 159-165.

- and - 1994. Karyological studies in Grain Amaranths. Cytologia 59: 25-30.

- and - 1995. Meiotic studies of spontaneous hybrids of Amaranthus. Genome Analysis. Plant Breeding 114: 448450.

Hürgin, G. 1987. Eimige Bemerkungen zu wenig bekanntne Amaranthus Sippen (Amaranthaceae). Mitteleuropas. Willdenovia 16: 453-478.

Kiehn, M., Vitek, E., Hellmayr, E., Walter, J., Tschentt, J., Justin, C. and Mann, E. 1991. Beriräge zur Flora von Österreich Chromosomenzählungen. Verh. Zoo.-Bot. Ges. Österreich 128: 19-39.

Levan, A., Fredga, K. and Sandberg, A. A. 1964. Nomenclature for centromeric position on chromosomes. Hereditas 52: 201-220.

Paiva, J. and Leitao, M. T. 1989. Números cromossómicos para alguns taxa da Africa Tropical II. Boc. Soc. Brot. Ser. 2: $117-130$.

Pal, M. and Pandey, R. M. 1989. Cytogenetics and evolution of grain amaranths. Aspects P1. Sci. 11: 323-336.

- and Khoshoo, T. M. 1982. Evolution and improvements of cultivated Amaranths IX. Cytogenetic relationships between the two basic chromosome numbers. J. Heredity 73: 353-356.

Palomino, G. and Rubí, R. 1991. Diferencias cromosómicas entre algunas especies y tipos del género Amaranthus distribuidos en Mexico. Primer Cong. Intern. Amaranto. (Oaxtepec, Morelos, Mexico): 24.

Price, H. J. 1988a. Nuclear DNA content variation within angiosperm species. Evol. Trend in Plants 2: 53-60.

- 1988b. DNA content variation among higher plants. Ann. Mo. Bot. Gard. 75: 1248-1257.

Queiros, R. 1989. Estudios citotaxonomicos en Amaranthus de Portugal. Lazaroa 11: 9-17.

Romero Zarco, C. 1986. A new method for estimating karyotype asymmetry. Taxon 35: 526-530.

Tito, C., Poggio, L. and Naranjo, C. A. 1991. Cytogenetic studies in the genus Zea 3. DNA content and heterochromatin in species and hybrids. Theor. Appl. Genet. 83: 58-64. 